\title{
Forage Potential of Winter Cereal/Legume Intercrops in Organic Farming
}

\author{
Marco Mariotti ${ }^{1 *}$, Alessandro Masoni ${ }^{1}$, Laura Ercoli ${ }^{2}$, Iduna Arduini ${ }^{1}$ \\ ${ }^{1}$ Dipartimento di Agronomia e Gestione dell'Agroecosistema, Università di Pisa \\ Via San Michele degli Scalzi 2, 56124 Pisa, Italy \\ ${ }^{2}$ Scuola Superiore di Studi Universitari e di Perfezionamento Sant'Anna \\ Piazza Martiri della Libertà 33, 56127 Pisa, Italy
}

Received: 3 April 2006. Accepted: 7 July 2006

\begin{abstract}
This research was performed to assess the potential of cereal/legume intercropping to enhance forage yield and quality when compared with cereal sole crops under the constrains imposed by UE organic farming regulations. Sole crops (SC) and intercrops (IC) of two winter cereals, barley (Hordeum vulgare L.) and durum wheat (Triticum durum Desf.), and two legumes, white lupin (Lupinus albus L.) and common vetch (Vicia sativa L.), were evaluated at two harvest times for dry matter yield (DMY), crude protein concentration (CPC), and nitrogen yield (NY). Yield values and dry matter concentration (DMC) were generally higher when cereals were at the hard dough compared to the late milk stage. On average, intercropping increased forage yield by $72 \%$, NY by $190 \%$, and CPC by $40 \mathrm{~g} \mathrm{~kg}^{-1}$, compared to cereal sole crops, but the choice of legume species affected the yield advantage and the composition of forage. Land equivalent ratio (LER) of intercrops was always higher than 1, ranging from 1.39 to 1.61. Intercropping also enhanced weed suppression, compared to sole crop.
\end{abstract}

Key-words: barley, common vetch, durum wheat, intercropping, organic farming, white lupin.

\section{Introduction}

In recent years, organic farming has widely developed and now represents an important section of agriculture. Originally, organic farming was first of all an ideological concept belonging to the alternative culture, in contrast with the current models of economic development and social organization. Today, organic farming has became a well established production system, that attracts both human and financial resources, is profitable and meets the demands of a fast-growing market. In Italy, the agricultural land in organic farming has risen from $\leq 1 \%$ in 1992 to $7 \%$ in 2004 (MiPAF, 2006).

Livestock production and cultivation of legume species are basic elements of organic farming systems, because the agronomic utilization of manure and biological nitrogen fixation are essential to supply nutrients to crops (Doyle and Topp, 2004). In Italy, 50\% of the land used for organic cultivations is covered with forage legumes, $20 \%$ with cereals, $20 \%$ with tree crops and $10 \%$ with other herbaceous crops. Among cereals, about $70 \%$ are represented by winter cereals, whereas maize constitutes only $7 \%$ (MiPAF, 2006).

The organic livestock production guidelines (UE Regulations 2092/91 and 1804/99) recommend that for cattle the daily intake forages (pasture, hay and silage) must be at least $60 \%$ with concentrates composed no more than $40 \%$ of the diet. Winter cereal grain is the most common concentrate in Italy and silages are generally produced with maize and winter cereals.

The production of hay with organic farming practices does not pose particular problems when forage legumes are used, whereas the pro-

* Corresponding Author: Tel.: +39 050 599111; Fax: +39 050 540633. E-mail address: marcom@agr.unipi.it. 
duction of concentrates and silages with grain cereals is much more difficult, because the absence of chemical fertilizers and herbicides drastically reduces their yield. In particular, forage yield of winter cereals is less affected than that of maize, because winter cereals require less nutrient input, are more competitive against weeds, and, at least in northern-central Italy, they do not require irrigation. Winter cereals are productive and ensile well (Crovetto et al., 1998; Edmisten et al., 1998a) but forage CPC is low (Cherney and Marten, 1982; Edmisten et al., 1998b; Juskiw et al., 2000).

Theunissen (1997) found that in organic farming, intercropping of a winter cereal with a legume provided higher forage yield and better silage quality than a winter cereal sole crop. Intercropping is defined as the simultaneous growing of two or more crop species in the same field (Andrews and Kassam, 1976). The major agronomic advantages of intercropping are higher yield, increased quality, higher ability to adapt to climatic and biotic stresses, owing to the mutual protection and support between consociated species (Trenbath, 1976). These advantages derive from better utilization of environmental resources (nutrients, water, and solar radiation) when the interspecies competition is weaker than intraspecific competition (Willey, 1985; Caporali et al., 1987). Besides, by intercropping legume species with grasses, nitrogen may be transferred from the former to the latter (Ofori and Stern, 1987, Heichel and Henjum, 1991). This transfer can be particularly important in absence of $\mathrm{N}$-fertilization, typical of organic farming (Jensen, 1996; Andersen et al., 2004). Without mineral $\mathrm{N}$ fertilization, barley/ pea, oat/pea, wheat/bean and oat/berseem clover intercropping increased forage yield by $20-50 \%$, compared to the winter cereals sole crop (Ghaffarzadeh, 1997; Ghanbari-Bonjar and Lee, 2003; Car et al., 2004).

The efficiency of an intercropping system, compared to sole cropping, can be evaluated by LER, defined as the relative land area (or growth resource) required when growing a sole crop to produce the yield achieved in intercropping (Mead and Willey, 1980). Barley/pea (Hauggaard-Nielsen et al., 2001; Andersen et al., 2004; Chen et al., 2004), oat/vetch (Ercoli et al., 1997; Mariotti et al., 1998), wheat/pea (Caporali et al., 1998) and wheat/bean intercrops (Ghan-
bari-Bonjar and Lee, 2003) had LER values greater than 1, indicating an intercropping advantage over sole cropping.

Generally, intercropping cereal and legume species produce a forage with a higher CPC than cereal sole crops, owing to the presence of legume species in the mixed forage. Increase in CPC was about $15 \mathrm{~g} \mathrm{~kg}^{-1}$ in the triticale/bean intercrop (Jedel and Helm, 1993), ranging from 20 to $40 \mathrm{~g} \mathrm{~kg}^{-1}$ in the barley/pea and oat/pea intercrops (Carr et al., 2004; Chen et al., 2004) and was about $60 \mathrm{~g} \mathrm{~kg}^{-1}$ in the wheat/pea (Salawu et al., 2001; Ghanbari-Bonjar and Lee, 2003).

Intercropping also enhances weed suppression, owing to the higher plant density that increases shading and competition for water and nutrients, reducing both germination and growth of weeds (Liebman et al., 1988). Marked reductions in weeds were recorded in wheat intercropped with bean, chickpea, lentil and pea (Bulson et al., 1990; Alam et al., 1997), and in barley/pea intercropping (Hauggaard-Nielsen et al., 2001).

A major problem with intercropping for forage is determining the optimal harvest time because the growth cycle of consociated species is often not synchronized. Dry matter concentration of forage is crucial to obtain good silage. The optimal DMC of forage ranges from 300 to $400 \mathrm{~g} \mathrm{~kg}^{-1}$ (Gardner and Wiggans, 1961; Edmisten et at., 1998a) and it is generally achieved by harvesting cereal crops during the milk to late milk stages (Ghanbari-Bonjar and Lee, 2003).

The objective of our research was to assess the potential of winter cereal/legume intercropping to enhance forage yield and quality when compared with cereal sole crops under the constraints imposed by European Union organic farming regulations. The species chosen, widely cultivated in the mediterranean area, were barley and durum wheat as winter cereals and white lupin and common vetch as legumes.

\section{Materials and methods}

The research was carried out in 2002-2003 at the Department of Agronomy and Agroecosystem Management of the University of Pisa, Italy. The study area was located on an alluvial plain in Tuscany $\left(43^{\circ} 40^{\prime} \mathrm{N}, 10^{\circ} 19^{\prime} \mathrm{E}\right)$. The climate is cold, humid Mediterranean with mean annual 
maximum and minimum daily air temperatures of 9.5 and $20.2{ }^{\circ} \mathrm{C}$ respectively, and precipitation of $971 \mathrm{~mm}$, with $663 \mathrm{~mm}$ received from November through June (Moonen et al., 2001).

Main soil physical and chemical properties were $33.9 \%$ sand, $20.8 \%$ silt, $45.3 \%$ clay, $7.2 \mathrm{pH}$, $21.5 \mathrm{~g} \mathrm{~kg}^{-1}$ organic matter (Walkley and Black method), $11.2 \mathrm{~g} \mathrm{~kg}^{-1}$ total $\mathrm{CaCO}_{3}$ (Scheibler method), $1.2 \mathrm{~g} \mathrm{~kg}^{-1}$ total nitrogen (Kjeldhal method), 43 ppm available P (Olsen method), 167 ppm available K (Dirks-Sheffer method).

Treatments were the sole crops of "Emilia" barley (B), "Creso" durum wheat (W), "Multitalia" white lupin (L), and "Nitra" common vetch $(\mathrm{V})$, and the intercrops of barley/lupin $(\mathrm{B} / \mathrm{L})$, barley/vetch $(\mathrm{B} / \mathrm{V})$, durum wheat/lupin $(\mathrm{W} / \mathrm{L})$, and durum wheat/vetch (W/V). Sole crops and intercrops were harvested at milk and dough ripening stage of cereals. The experiment was arranged in the field in a split-plot design, with forage treatment as the main plot and harvest time as the subplot, with three replications. Subplot dimensions were 5 by $10 \mathrm{~m}$. The previous crop was alfalfa cultivated from 1999 to 2002 without fertilizer or herbicide applications. Soil preparation consisted in medium depth plowing $(30 \mathrm{~cm})$, carried out in October 2002. Final seed bed preparation was carried out just prior to sowing by harrowing twice, with a disc harrow and with a rotating harrow. The symbiosis between white lupin and its specific rhizobium (Rhizobium lupinii) was promoted by mixing the seeds of white lupin with slightly wet soil where a white lupin crop had been cultivated in the previous year. Sowing took place on 11 November 2002, in 15-cm spaced rows for the sole crops and $7.5-\mathrm{cm}$ spaced rows for the intercrops. Intercrops were sown in a 1:1 additive design in alternate rows. Seed densities for $\mathrm{SC}$ and IC were 400 viable seeds per $\mathrm{m}^{-2}$ for barley and durum wheat, 80 for white lupin, and 150 for common vetch. Throughout the study, the field was managed according to organic agriculture guidelines with no use of fertilizers or herbicides.

To determine plant population, total number of emerged plants was counted two weeks after emergence in an area $0.65 \mathrm{~m}^{2}$ in the center of each plot.

Forage was harvested at late milk stage (stage 77) and hard dough stage of cereals (stage 87) as descibed by Zadoks et al. (1974).
For white lupin and common vetch the scales of Lopez-Bellido and Fuentes (1990) and Caballero et al. (1996a) were used, respectively. Barley reached the late milk stage on 21 May and the hard dough stage on 30 May. Durum wheat was harvested about ten days later than barley, reaching late milk stage on 2 June and hard dough stage on 10 June. At these dates white lupin was between $R_{4}$ (beginning of pod filling) and $\mathrm{R}_{8}$ (maturation) stage and common vetch was at pod filling on both dates. Differences in the phenology within each species, both SC and ICs, were not observed. The forage grown in $1 \mathrm{~m}^{2}$ area was cut at $5 \mathrm{~cm}$ above soil level and was separated in cereals, legumes, and weeds. Winter cereal and legume plants were divided into stems, leaves, and inflorescences (spikes and/or pods). Plant parts were oven dried for dry matter determination at $75{ }^{\circ} \mathrm{C}$ to constant weight and analyzed for nitrogen concentration by the microKjeldahl method (Bremnar, 1965). Crude protein concentration was calculated multiplying $\mathrm{N}$ concentration by 6.25 (AOAC, 1990) and $\mathrm{N}$ yield was obtained by multiplying the $\mathrm{N}$ concentration by DMY.

The resource complementarity of the intercrops was measured using the land equivalent ratio (LER). According to Mead and Willey (1980) land equivalent ratio for a cereal/legume intercrop is the sum of the partial LER $\left(\mathrm{LER}_{\mathrm{X}}\right)$ values for cereal $\left(\operatorname{LER}_{C}\right)$ and legume $\left(\mathrm{LER}_{\mathrm{L}}\right)$ :

$$
\begin{gathered}
\mathrm{LER}_{\mathrm{X}}=\mathrm{Yic} / \mathrm{Ysc} \\
\mathrm{LER}=\mathrm{LER}_{\mathrm{C}}+\mathrm{LER}_{\mathrm{L}}
\end{gathered}
$$

where Yic and Ysc are respectively intercropping and sole cropping forage DMY or NY of crops.

The competitive ability of the companion crops was calculated with the aggressivity index (A), according to Snaydon (1991). This index is a measure of the ability of one component to obtain limiting resources, when grown in mixtures with another component, compared with its ability to utilize those resources when grown in pure stands. Aggressivity index, calculated for the cereal component, can be expressed as:

$$
\mathrm{A}=\mathrm{LER}_{\mathrm{C}}-\mathrm{LER}_{\mathrm{L}}
$$

Data were analyzed by analysis of variance to test the effect of the forage treatment (FT), the harvest time $(\mathrm{HT})$, and the FT $\times \mathrm{HT}$ interaction. Significantly $(\mathrm{P}<0.05)$ different means 
were separated by the least significant difference test (Snedecor and Cochran, 1980).

\section{Results and discussion}

\subsection{Forage dry matter concentration and yield and legume proportion}

The FT $\times$ HT interaction was significant only for forage DMC. The ranking of forage treatments did not change at the two harvest stages: thus, the magnitude of differences between harvest times within forages treatments lead to the interaction.

Dry matter concentration of forage increased from the first to the second harvest, as was expected owing to the progress of cereal biological cycle (Table 1). According to Gardner and Wiggans (1961) and Edmisten et at. (1998a), DMC of barley and wheat sole crops forages was optimal for ensiling (inside the 300-400 g $\mathrm{kg}^{-1}$ range) at milk stage and was slightly higher than optimum at dough stage. Dry matter concentration of lupin sole crop forage was always lower than the recommended values for ensiling, and that of vetch was lower than the minimum threshold at the first harvest and within the optimal range at the second harvest (Table 1). At milk stage of cereals, both lupin intercrops had suitable forage DMC for ensiling, while DMC of both vetch intercrops was too low. Forage DMC of all intercrops harvest-

Table 1. Dry matter concentration $\left(\mathrm{g} \mathrm{kg}^{-1}\right)$ of the forages of intercrops and sole crops at the first and the second harvest, corresponding to milk and hard dough stage of cereals. Lupin $_{B}$ and Vetch $_{B}$ were SC harvested at the barley ripening stages, Lupin ${ }_{\mathrm{W}}$ and Vetch $_{\mathrm{W}}$ were SC harvested at the wheat ripening stages.

\begin{tabular}{|c|c|c|}
\hline \multicolumn{3}{|c|}{ Dry matter concentration $\left(\mathrm{g} \mathrm{kg}^{-1}\right)$} \\
\hline Forage treatment & First harvest & Second harvest \\
\hline Barley/Lupin & $307.0 \mathrm{ct}$ & $382.5 \mathrm{~d}$ \\
\hline Barley/Vetch & $260.0 \mathrm{~b}$ & $307.2 \mathrm{c}$ \\
\hline Wheat/Lupin & $304.4 \mathrm{c}$ & $384.4 \mathrm{~d}$ \\
\hline Wheat/Vetch & $289.2 \mathrm{c}$ & $376.4 \mathrm{~d}$ \\
\hline Barley & $370.0 \mathrm{~d}$ & $430.1 \mathrm{e}$ \\
\hline Wheat & $380.3 \mathrm{~d}$ & $460.0 \mathrm{e}$ \\
\hline $\operatorname{Lupin}_{B}$ & $190.0 \mathrm{a}$ & $210.3 \mathrm{a}$ \\
\hline Lupin $_{\mathrm{W}}$ & $210.0 \mathrm{a}$ & $230.1 \mathrm{ab}$ \\
\hline Vetch $_{B}$ & $220.4 \mathrm{ab}$ & $280.2 \mathrm{c}$ \\
\hline Vetch $_{W}$ & $265.1 \mathrm{c}$ & $355.0 \mathrm{~d}$ \\
\hline
\end{tabular}

$\uparrow$ Values in any row or column followed by the same letter are not significantly different at $P \leq 0.05$. ed at cereal dough stage was suitable for ensiling.

Owing to the lack of significance of the interaction $\mathrm{FT} \times \mathrm{HT}$ for all other measured variables, the higher forage yield, and the more suitable DMC of forage at the hard dough stage of each cereal species, only differences among FT from this HT will be reported and discussed. Differences in the main effect of HT will be discussed.

Dry matter yield was generally higher when cereals are at the hard dough stage than in the late milk stage ( $700.3 \mathrm{vs} 781.3 \mathrm{~g} \mathrm{~m}^{-2}$ for the late milk and hard dough stages, respectively). Dry matter concentration of forage may be too high, however, for ensiling cereal sole crops at the hard dough stage while DMC of legume sole crops may still be too low, except for vetch harvested when wheat is in the hard dough stage (Table 1). Our results demonstrate that intercropping cereals with legumes allows ensiling at hard dough stage of cereals, compensating with higher dry matter yield for the decrease of energy content that normally occurs as cereals mature (Crovetto et al., 1998).

At dough stage of cereals, weed biomass was high in lupin SC, low in cereals SC and nearly absent in common vetch SC (Table 2). Between cereals, values were higher in wheat than in barley (Table 2). Compared with cereal SC, intercropping reduced weed biomass by about $70 \%$ in the lupin intercrops and by $100 \%$ in the vetch IC. This was expected because we applied an additive design of intercropping, where the components were seeded at the sole crop rate and the final plant density was the sum of the densities of the sole crops. Among the four sole crops tested, the white lupin suffered the highest weed competition. Lupin production is highly dependent on herbicide use in conventional farming, greatly suffering from weed competition, owing to the initial slow growth rate, with rosette shape that prevents the soil cover before winter (Lopez-Bellido and Fuentes, 1990; Huyghe, 1991; Perry et al., 1998). Common vetch, in contrast, does not suffer by weed competition, owing to its rapid growth and soil cover. Between cereals, barley seems to compete better than wheat with weeds, probably due to the greater early growth rate of barley compared to wheat (Cousens, 1996).

Compared to conventional farming yield in Italy, organic management reduced DMY of cereal SCs by $40-50 \%$ (De Franchi et al., 1995; 
Table 2. Cereal, legume, total forage and weed dry matter of intercrops and sole crops at hard dough stage of cereals. Lupin $_{B}$ and Vetch ${ }_{B}$ were SC harvested at the barley ripening stages, Lupin ${ }_{W}$ and Vetch $_{W}$ were SC harvested at the wheat ripening stages.

\begin{tabular}{lcccc}
\hline Forage treatment & Cereal & Legume & Total forage & Weeds \\
\cline { 2 - 4 } & & & & \\
\hline Barley/Lupin & $618.3 \mathrm{e} \dagger$ & $346.4 \mathrm{a}$ & $964.7 \mathrm{e}$ & $10.5 \mathrm{a}$ \\
Barley/Vetch & $358.7 \mathrm{~b}$ & $526.1 \mathrm{c}$ & $884.8 \mathrm{~d}$ & $0.0 \mathrm{a}$ \\
Wheat/Lupin & $565.7 \mathrm{~d}$ & $394.7 \mathrm{~b}$ & $960.4 \mathrm{e}$ & $23.0 \mathrm{ab}$ \\
Wheat/Vetch & $311.3 \mathrm{a}$ & $573.2 \mathrm{~d}$ & $884.5 \mathrm{~d}$ & $0.0 \mathrm{a}$ \\
Barley & $554.1 \mathrm{~cd}$ & - & $554.1 \mathrm{a}$ & $36.0 \mathrm{~b}$ \\
Wheat & $519.7 \mathrm{c}$ & - & $519.7 \mathrm{a}$ & $65.3 \mathrm{c}$ \\
Lupin $_{\mathrm{B}}$ & - & $702.8 \mathrm{e}$ & $702.8 \mathrm{~b}$ & $104.6 \mathrm{~d}$ \\
Lupin $_{\mathrm{W}}$ & - & $758.0 \mathrm{f}$ & $758.0 \mathrm{bc}$ & $124.2 \mathrm{~d}$ \\
Vetch $_{\mathrm{B}}$ & - & $710.9 \mathrm{e}$ & $710.9 \mathrm{~b}$ & $0.0 \mathrm{a}$ \\
Vetch $_{\mathrm{W}}$ & - & $790.2 \mathrm{f}$ & $790.2 \mathrm{c}$ & $0.0 \mathrm{a}$ \\
\hline
\end{tabular}

$\dagger$ In each column, values followed by the same letter are not significantly different at $P \leq 0.05$.

Villegas et al., 2001), and lupin by about $25 \%$ (Fagnano and Postiglione, 1994), while it did not modify that of vetch (Ercoli et al., 1997). In winter cereals, yield was probably reduced by nitrogen deficiency, indicating that residual nitrogen from the preceding alfalfa was not sufficient to achieve the maximum cereal yield. The yield of lupin was reduced by weed competition while the yield of vetch was not affected, owing to its strong competition with weeds and to its N-fixing capacity (Papastylianou and Danso, 1991).

Totale forage yield was greater for all intercrops compared to sole crops (Table 2). The forage yield of lupin intercrops was about 10\% higher than vetch ICs. The proportion of legumes in the IC forage was highly different between lupin and vetch ICs: lupin constituted $36 \%$ of the forage yield in the $\mathrm{B} / \mathrm{L}$ intercrop and $41 \%$ in the W/L IC, while vetch constituted $60 \%$ of the forage yield in the $\mathrm{B} / \mathrm{V}$ intercrop and $65 \%$ in the W/V IC. In the cereal/vetch ICs these values are higher than minimum threshold value of $50 \%$ vetch content, that Caballero et al. (1996b) stated would ensure a high quality cereal/vetch forage.

Compared to SC yield, in the cereal/lupin ICs the forage yield of cereals increased and that of lupin decreased. Barley gained more than wheat with lupin as companion crop and lost less than wheat with vetch as companion crop (Table 2). These results are in agreement with those of Counsens (1996), Caporali et al. (1998), and Ross et al. (2004): they concluded that barley was more competitive than wheat and attribute this advantage to the early growth rate of barley, that is greater than wheat: as the results barley had a greater ability to suppress the companion crop.

Jannash and Martin (1999) found that lupin competed poorly with small grain cereals, which have a higher initial growth rate. In our research lupin SC yield was reduced in the intercropping with cereals (Table 2).

In the cereal/vetch ICs the forage yield of all three species decreased. Cereal and vetch yield was reduced by about $40 \%$ and that of vetch by about $20 \%$, compared to SC yields. In other research the vetch suffered due to competition by intercropped winter cereals (Roberts et al., 1989; Caballero et al., 1995). This unexpected result could be explained by the absence of nitrogen fertilization characteristic of the organic farming methods in which vetch can compete better with cereals (Moreira, 1989).

Intercropping did not appreciably modify the plant population (Table 3). The percentage of planted seeds that emerged as plants ranged from 77 to $91 \%$ in SC plots and 75 to $90 \%$ in IC plots. These data indicate that intercropping may not influence plant population establishment of the cereal and legume crops, presumably because interspecific competition for growth resources among seedlings is minimal.

The proportion of forage dry matter as inflorescences was modified by intercropping in the legumes but not in the cereals (Table 3). Compared to SC, the number of reproductive plant parts was reduced in the lupin component of the cereal/lupin ICs, and was increased in the vetch component of the cereal/vetch ICs, as op- 
Table 3. Plant population, proportion of forage DM as inflorescences, and number of inflorescences per plant of the sole crops and companion crops at hard dough stage of cereals. Lupin $_{\mathrm{B}}$ and $\mathrm{Vetch}_{\mathrm{B}}$ were $\mathrm{SC}$ harvested at the barley ripening stages, Lupin $_{\mathrm{W}}$ and Vetch $\mathrm{W}$ were SC harvested at the wheat ripening stages.

\begin{tabular}{|c|c|c|c|c|c|c|}
\hline \multirow{4}{*}{ Forage treatment } & \multicolumn{2}{|c|}{ Plant population } & \multicolumn{4}{|c|}{ Inflorescences } \\
\hline & & & \multicolumn{2}{|c|}{ Proportion } & \multicolumn{2}{|c|}{ Number } \\
\hline & \multirow{2}{*}{\multicolumn{2}{|c|}{$\stackrel{\text { Cereal }}{\longrightarrow}\left(\mathrm{N} \mathrm{m}^{-2}\right) \stackrel{\text { Legume }}{ }$}} & Cereal & Legume & Cereal & Legume \\
\hline & & & \multicolumn{2}{|c|}{$-\left(\mathrm{g} \mathrm{kg}^{-1}\right.$ forage $)$} & \multicolumn{2}{|c|}{$\left(\mathrm{N}\right.$ plant $\left.{ }^{-1}\right)$} \\
\hline Barley/Lupin & $351 \mathrm{a} \dagger$ & $61 \mathrm{a}$ & $458 \mathrm{ab}$ & $197 \mathrm{a}$ & $1.4 \mathrm{~b}$ & $1.5 \mathrm{a}$ \\
\hline Barley/Vetch & $344 \mathrm{a}$ & $113 \mathrm{~b}$ & $464 \mathrm{ab}$ & $236 \mathrm{~b}$ & $1.1 \mathrm{ab}$ & $6.2 \mathrm{f}$ \\
\hline Wheat/Lupin & $340 \mathrm{a}$ & $60 \mathrm{a}$ & $430 \mathrm{a}$ & $253 \mathrm{~b}$ & $1.2 \mathrm{ab}$ & $1.9 \mathrm{~b}$ \\
\hline Wheat/Vetch & $340 \mathrm{a}$ & $112 \mathrm{~b}$ & $433 \mathrm{a}$ & $346 \mathrm{~d}$ & $0.9 \mathrm{a}$ & $6.6 \mathrm{~g}$ \\
\hline Barley & $363 \mathrm{a}$ & - & $480 \mathrm{~b}$ & - & $1.2 \mathrm{ab}$ & - \\
\hline Wheat & 359 a & - & $449 \mathrm{ab}$ & - & $1.1 \mathrm{ab}$ & - \\
\hline Lupin $_{B}$ & - & $64 \mathrm{a}$ & - & $323 \mathrm{~cd}$ & - & $5.0 \mathrm{c}$ \\
\hline Lupin $_{\mathrm{W}}$ & - & $63 \mathrm{a}$ & - & $404 \mathrm{e}$ & - & $5.3 \mathrm{~cd}$ \\
\hline Vetch $_{B}$ & - & $123 \mathrm{~b}$ & - & $199 \mathrm{a}$ & - & $5.6 \mathrm{de}$ \\
\hline Vetch $_{W}$ & - & $116 \mathrm{~b}$ & - & $297 \mathrm{c}$ & - & $5.8 \mathrm{ef}$ \\
\hline
\end{tabular}

$\dagger$ In each column, values followed by the same letter are not significantly different at $P \leq 0.05$.

posed to mean weight of inflorescences per plant, which was unaffected by intercropping. In the cereal/lupin the interspecific competition with the cereals reduced the number of inflorescences of the lupin by $70 \%$ in the $\mathrm{B} / \mathrm{L}$ and by $64 \%$ in the W/L IC.

Others have reported that lupin sole crop responded to environmental stress primarily by decreasing the number of reproductive organs (Herbert, 1977; Withers, 1979), and similar results were reported for lupin intercropping (Carruthers et al., 2000).

In the cereal/vetch IC, however, the facilitation effect was observed, in that number of the inflorescences per plant increased by $11 \%$ in the $\mathrm{B} / \mathrm{V}$ and by $14 \%$ in the W/V IC. This higher pro- portion of inflorescences in cereal/vetch ICs, compared to the SCs, was probably related to the higher amount of intercepted radiation by the climbing vetch with the cereals as tutor (Ercoli et al., 1993).

\subsection{Forage crude protein concentration and ni- trogen yield}

Crude protein concentration of forage of all intercrops and sole crops did not vary according to harvest stage, while forage NY increased from milk to hard dough stage (126.7 vs 141.0 $\mathrm{kg} \mathrm{ha}{ }^{-1} \mathrm{~N}$ for the late milk and hard dough stages, respectively). As expected, the CPC of the forage was lower in the winter cereal SCs than in the legume ones (Table 4).

Table 4. Crude protein concentration and nitrogen yield of cereals, legumes and total forage harvested at hard dough stage of cereals. Lupin ${ }_{B}$ and Vetch ${ }_{B}$ were SC harvested at the barley ripening stages, Lupin $_{W}$ and Vetch $_{W}$ were SC harvested at the wheat ripening stages.

\begin{tabular}{|c|c|c|c|c|c|c|}
\hline \multirow[b]{2}{*}{ Forage treatment } & \multicolumn{3}{|c|}{ Crude protein } & \multicolumn{3}{|c|}{ Nitrogen yield } \\
\hline & Cereal & $\begin{array}{r}\text { Legume } \\
-\left(\mathrm{g} \mathrm{kg}^{-1}\right)\end{array}$ & Total forage & Cereal & $\begin{array}{l}\text { Legume } \\
\left(\mathrm{kg} \mathrm{ha}^{-1}\right)\end{array}$ & Total forage \\
\hline Barley/Lupin & $62.6 \mathrm{a} \dagger$ & $127.0 \mathrm{a}$ & $85.7 \mathrm{~b}$ & $61.9 \mathrm{~d}$ & $70.4 \mathrm{a}$ & $132.3 \mathrm{~b}$ \\
\hline Barley/Vetch & $61.3 \mathrm{a}$ & $151.6 \mathrm{bc}$ & $115.0 \mathrm{c}$ & $35.2 \mathrm{a}$ & $127.6 \mathrm{~b}$ & $162.9 \mathrm{c}$ \\
\hline Wheat/Lupin & $61.7 \mathrm{a}$ & $115.2 \mathrm{a}$ & $83.7 \mathrm{~b}$ & $55.9 \mathrm{~cd}$ & $72.7 \mathrm{a}$ & $128.6 \mathrm{~b}$ \\
\hline Wheat/Vetch & $60.3 \mathrm{a}$ & $150.3 \mathrm{bc}$ & $118.6 \mathrm{c}$ & $30.1 \mathrm{a}$ & $137.8 \mathrm{c}$ & $167.9 \mathrm{~cd}$ \\
\hline Barley & 59.9 a & - & 59.9 a & $53.1 \mathrm{bc}$ & - & $53.1 \mathrm{a}$ \\
\hline Wheat & 58.8 a & - & $58.8 \mathrm{a}$ & $48.9 \mathrm{~b}$ & - & $48.9 \mathrm{a}$ \\
\hline Lupin $_{B}$ & - & $146.3 \mathrm{bc}$ & $146.3 \mathrm{~d}$ & - & $164.5 \mathrm{~d}$ & $164.5 \mathrm{~cd}$ \\
\hline $\operatorname{Lupin}_{\mathrm{W}}$ & - & $140.2 \mathrm{~b}$ & $140.2 \mathrm{~d}$ & - & $170.1 \mathrm{de}$ & $170.1 \mathrm{~cd}$ \\
\hline Vetch $_{B}$ & - & $154.9 \mathrm{c}$ & $154.9 \mathrm{~d}$ & - & $176.2 \mathrm{e}$ & $176.2 \mathrm{~d}$ \\
\hline Vetch $_{W}$ & - & $149.9 \mathrm{bc}$ & $149.9 \mathrm{~d}$ & - & $189.5 \mathrm{f}$ & $189.5 \mathrm{e}$ \\
\hline
\end{tabular}

\footnotetext{
$\dagger$ In each column, values followed by the same letter are not significantly different at $P \leq 0.05$
} 
Crude protein concentration of forage was enhanced by intercropping, compared to cereal SCs (Table 4). The increase was higher for the cereal/vetch IC than for the cereal/lupin IC, likely because of differences in legume proportion of total yield of the ICs. For this reason the increase of CPC was higher in the cereal/vetch IC (about $58 \mathrm{~g} \mathrm{~kg}^{-1}$ ) than in the cereals/lupin IC (about $25 \mathrm{~g} \mathrm{~kg}^{-1}$ ). Similar results were obtained by Ghanbari-Bonjar and Lee (2003) with wheat/bean IC and by Carr et al. (2004) with barley/pea IC.

Crude protein concentration of cereals and vetch was not modified by IC while CPC of lupin was reduced (Table 4). The decrease was related to the high reduction in the weight of inflorescences in the intercropped plants, since CPC of leaves, stems and inflorescences of the lupin did not vary as a consequence of intercropping (data non shown).

Forage NY (Table 4) was lowest in SC cereals and highest in SC vetch. Intercropping produced higher NY than SC cereals, nearly increasing them to the level of SC vetch. As average, the NY of lupin intercrops was 2.6 times and that of vetch IC was 3.2 times higher than NY of cereals SC. The NY of vetch ICs was higher than lupin ICs.

In the cereal/lupin ICs, NY of the legume was reduced and that of the cereal was increased, compared to SC values. Both cereal/lupin ICs had about $8 \mathrm{~kg} \mathrm{ha}^{-1}$ higher NY than cereal SCs (Table 4). The advantage of both cereal/lupin ICs was probably due to this higher nitrogen availability to the cereal by the lupin. Similar results were obtained by Palmason et al. (1992), owing to direct $\mathrm{N}$ transfer from lupin to the intercropped italian ryegrass. In addition, several have reported that lupin cultivation can improve the yield of the subsequent winter cereal crop, attributing the improvement to the residual N (Jensen et al., 2004; Payne et al., 2004). Others related the positive effect of the intercropping with lupin to improved $\mathrm{P}$ nutrition of the cereal, due to solubilization of $\mathrm{P}$ by the legume roots (Suong et al., 2005). In our research, however, this was not likely to occur due to the high $\mathrm{P}$ content of the soil (Zentner et al., 1992). In addition, no visual symptoms of $\mathrm{P}$ deficiencies in the barley and wheat SC were observed (Ozturk et al., 2005).

In the cereal/vetch ICs, NY of all species was reduced, respect to SC values, and the reductions that were consistent with the DMY reductions. In this research, the $\mathrm{N}$ transfer from vetch to companion cereals was not evidenced. Other Authors have pointed out that the direct $\mathrm{N}$ transfer from vetch to the intercropped cereal crop is uncertain (Papastylianou and Danso, 1991; Kurdali et al., 1996).

\subsection{Land equivalent ratio}

When LER $<1$ there is a disadvantage to intercropping and the resources are used more efficiently by SC than by IC. When LER $=1$ there is no intercropping advantage nor disadvantage, respect to the sole cropping system; when LER $>1$ there is an intercropping advantage in terms of improved use of environmental resources for plant growth (Mead and Willey, 1980).

All four intercrops had total LER greater than 1 (Table 5), both on dry weight and on nitrogen yield basis, indicating a high yield advantage and a high resource complementarity from intercropping. Total LER was higher in lupin ICs than in vetch ICs. To obtain the same yield of the cereal/lupin ICs, SCs would require $60 \%$ higher land area, while to obtain the same yield of the cereal/vetch ICs, SCs would require $40-50 \%$ higher land area (Table 5). Partial LER

Table 5. Cereals and legumes partial and total Land Equivalent Ratio (LER) and Aggressivity index (A) of the intercrops on a dry matter and nitrogen yield basis.

\begin{tabular}{|c|c|c|c|c|c|c|c|c|}
\hline \multirow{2}{*}{ Intercropping } & \multicolumn{4}{|c|}{ Dry Matter basis } & \multicolumn{4}{|c|}{ Nitrogen Yield basis } \\
\hline & $\mathrm{LER}_{\mathrm{C}}^{\dagger}$ & $\mathrm{LER}_{\mathrm{L}}$ & LER & A & $\mathrm{LER}_{\mathrm{C}}$ & $\mathrm{LER}_{\mathrm{L}}$ & LER & A \\
\hline Barley/Lupin & $1.12 \mathrm{a} \rrbracket$ & $0.49 \mathrm{a}$ & $1.61 \mathrm{a}$ & $0.72 \mathrm{a}$ & $1.17 \mathrm{a}$ & $0.43 \mathrm{a}$ & $1.59 \mathrm{a}$ & $0.74 \mathrm{a}$ \\
\hline Barley/Vetch & $0.68 \mathrm{~b}$ & $0.78 \mathrm{~b}$ & $1.46 \mathrm{~b}$ & $-0.09 \mathrm{~b}$ & $0.70 \mathrm{~b}$ & $0.76 \mathrm{~b}$ & $1.46 \mathrm{~b}$ & $-0.06 \mathrm{~b}$ \\
\hline Wheat/Lupin & $1.09 \mathrm{a}$ & $0.52 \mathrm{a}$ & $1.61 \mathrm{a}$ & $0.57 \mathrm{c}$ & $1.14 \mathrm{a}$ & $0.43 \mathrm{a}$ & $1.57 \mathrm{a}$ & $0.71 \mathrm{a}$ \\
\hline Wheat/Vetch & $0.63 \mathrm{c}$ & $0.76 \mathrm{~b}$ & $1.39 \mathrm{~b}$ & $-0.13 \mathrm{~d}$ & $0.65 \mathrm{c}$ & $0.77 \mathrm{~b}$ & $1.41 \mathrm{~b}$ & -0.12 \\
\hline
\end{tabular}

$\dagger \mathrm{LER}_{\mathrm{C}}$ and $\mathrm{LER}_{\mathrm{L}}$ represent LER of cereals and legumes, respectively;

II In each column, values followed by the same letter are not significantly different at $P \leq 0.05$. 
shows the contribution of each species in the ICs to total LER, thus demonstrating which species has mainly benefited from the association. In an additive design, partial LER values greater than 1.0 indicate a stimulus, partial LER values equal to 1.0 indicate no interaction and partial LER values lower than 1.0 indicate a competition between species (Austin et al., 1988).

In these ICs the cereals received a stimulus by the presence of the lupin, with an expected yield advantage up to $17 \%$ over SCs. Barley and wheat were not complementary to lupin, however, because the cereal dry matter and NY advantage were lower than the lupin disadvantage. Partial LER values of the lupin was low, but these values were consistent with those reported by Jannasch and Martin (1999) for wheat/lupin IC.

Aggressivity index indicates that in the cereal/lupin ICs cereals were dominant, and barley exhibited a higher competitive ability than wheat (Table 5). In both cereal/vetch ICs both species suffered from inter-specific competition. The disadvantage was higher for the cereals than for the legume, however, based on LER, suggesting that the legume was dominant in cereal/vetch ICs.

\section{Conclusions}

This experiment, carried out under the constraints imposed by UE organic farming guidelines (i.e. without addition of chemical input), has analyzed the possibility of improving silage yield and quality of cereals by intercropping with legume species.

Forage yield was increased by intercropping and, owing to the high CPC of legume species, NY also increased. On average, intercropping increased DMY by $72 \%$, NY by $190 \%$, and CPC by $40 \mathrm{~g} \mathrm{~kg}^{-1}$, compared to cereal sole crops, but the choice of legume species affects the yield and quality advantages. Cereals were the dominant species in the cereal/lupin ICs, and vetch was the dominant species in the cereal/vetch ICs. If the objective is to maximize dry matter yield, intercropping barley or durum wheat with white lupin is the best choice, while if the objective is to maximize $\mathrm{N}$ yield the best choice is the intercrop with common vetch. Moreover, silage harvest at cereal hard dough stage is rec- ommended to increase dry matter and crude protein yield and to obtain a dry matter concentration of the forage suitable to direct ensiling.

Further research, however, is necessary to verify the possibility of producing good quality silage from these forages. There likely are no problems for the cereal/lupin forage, whereas the CPC of the cereal/vetch forage could be too high to properly ensile: if that is the case the vetch seeding proportion could probably be reduced.

\section{References}

Alam M.Z., Rashid M.A., Mamin M.S.I., Mamun A.A. 1997. Intercropping effect on weed infestation in wheat. Bangladesh J. Sci. Ind. Res., 32:311-316.

Andersen M.K., Hauggaard-Nielsen H., Ambus P., Jensen E.S. 2004. Biomass production, symbiotic nitrogen fixation and inorganic $\mathrm{N}$ use in dual and tricomponent annual intercrops. Plant Soil, 266:273-287.

Andrews D.J., Kassam A.H. 1976. The importance of multiple cropping in increasing world food supplies. In: Papendick P.A., Sanchez P.A., Triplett G.B. (eds): Multiple Cropping, 1-10. ASA Special Publication 27. ASA, SSSA, CSSA, Madison, WI.

AOAC 1990. Official methods of analysis. 15th edition, AOAC, Arlington, VA.

Austin M.P., Fresco L.F.M., Nicholls A.O., Groves R.H., Kaye P.E. 1988. Competition and Relative Yield: Estimation and Interpretation at Different Densities and Under Various Nutrient Concentrations Using Silybum Marianum and Cirsium Vulgare, J. Ecol., 76:157-171.

Bremnar T.M. 1965. Total nitrogen. In: C.A. Black et al. (eds.): Methods of soil analysis. Part 2, 1149-1179. Agron. Monogr. 9., ASA and SSSA, Madison, WI.

Bulson H.A.J., Snaydon R.W., Stopes C.E. 1990. Intercropping autumn-sown field beans and wheat: effects on weeds under organic farming conditions. In: R. Unwin, (ed.): Organic and Low Input Agriculture, 5562. British Crop Protection Council Monograph 45, Bracknell, UK.

Caballero R., Goicoechea E.L., Hernaiz P.J. 1995. Forage yields and quality of common vetch and oat sown at verying seeding ratios and seeding rates of vetch. Field Crop Res., 41:135-140.

Caballero R., Barro C., Rebolè A., Arauzo M., Hernaiz P.J. 1996a. Yield components and forage quality of common vetch during pod filling. Agron. J., 88:797-800.

Caballero R., Rebolè A., Barro C., Alzueta C., Trevino J., Garcia C. 1996b. Farming practices and chemical bases for a proposed quality standard of vetch-cereal hays. Field Crop Res., 47:181-189. 
Caporali F., Paolini R., Campiglia E. 1987. Intercropping. Part I. Biological bases and yield advantages. Riv. Agron., 21:3-17.

Caporali F., Campiglia E., Paolini R., Mancinelli R. 1998. The effect of crop species, nitrogen fertilization and weeds on winter cereal/pea intercropping. Ital. J. Agron., 2:1-9.

Carr P.M., Horsley R.D., Poland W.W. 2004. Barley, oat, and cereal-pea mixtures as dryland forages in the northern great plains. Agron. J., 96:677-684.

Carruthers K., Prithiviraj B., Fe Q., Cloutier D., Martin R.C., Smith D.L. 2000. Intercropping corn with soybean, lupin and forages: yield component responses. Eur. J. Agron., 12:103-115.

Chen C., Westcott M., Neil K., Wichman D., Knox M. 2004. Row configuration and nitrogen application for barley-pea intercropping in Montana. Agron. J., 96:1730-1738.

Cherney F.P., Marten G.C. 1982. Small grain crop forage potential. II. Interrelationships among biological, chemical, morphological, and anatomical determinants of quality. Crop Sci., 22:240-245.

Cousens R.D. 1996. Comparative growth of wheat, barley, and annual ryegrass (Lolium rigidum) in monoculture and mixture. Aust. J. Agr. Res., 47:449-464.

Crovetto G.M., Galassia G., Rapettia L., Sandruccia A., Tamburinia A. 1998. Effect of the stage of maturity on the nutritive value of whole crop wheat silage. Livest. Prod. Sci., 55:21-32.

De Franchi A.S., Gherbin P., Monteleone M., Pardo A. 1995. Shoot and root growth and water uptake of barley genotypes (Hordeum spp.) with different vegetative habitus in a hilly area of southern Italy. Riv. Agron., 29:48-59.

Doyle C.J., Topp C.F.E. 2004. The economic opportunities for increasing the use of forage legumes in north European livestock systems under both conventional and organic management. Renew. Agr. Food Syst., 19:15-22.

Edmisten K.L., Green J.T., Mueller J.P., Burns J.C. 1998a. Winter annual small grain forage potential. I. Dry matter yield in relation to morphological characteristics of four small grain species at six growth stages. Commun. Soil Sci. Plan., 29:867-879.

Edmisten K.L., Green J.T., Mueller J.P., Burns J.C. 1998b. Winter annual small grain forage potential. II. Quantification of nutritive characteristics of four small grain species at six growth stages. Commun. Soil Sci. Plan., 29:881-899.

Ercoli L., Mariotti M., Masoni A. 1997. Radiation interception of oat/vetch intercrop. Riv. Agron., 31:658665.

Fagnano M., Postiglione L. 1994. Productive behaviour of sweet cultivars of Lupinus albus in Southern Italy. In: Proceedings of the VII International Lupin Conference, Evora, Portugal, 362-364.

Gardner F.P., Wiggans O.C. 1961. Yield, moisture, and crude protein composition of spring oat cut for silage at different stages of maturity. Agron. J., 53:251-254.

Ghaffarzadeh M. 1997. Economic and biological benefits of intercropping berseem clover with oat in cornsoybean-oat rotations. J. Prod. Agric., 10:314-319.

Ghanbari-Bonjar A., Lee H.C. 2003. Intercropped wheat (Triticum aestivum L.) and bean (Viacia faba L.) as a whole-crop forage: effect of harvest time on forage yield and quality. Grass Forage Sci., 58:28-36.

Hauggaard-Nielsen H., Ambusa P., Jensen E.S. 2001. Interspecific competition, $\mathrm{N}$ use and interference with weeds in pea-barley intercropping. Field Crop Res., 70:101-109.

Heichel G.H., Henjum K.I. 1991. Dinitrogen fixation, nitrogen transfer and productivity of forage grasslegume communities. Crop Sci., 31:202-208.

Herbert S.J. 1977. Growth and grain yield of Lupinus albus at different plant populations. New Zeal. J. Agr. Res., 20:459-465.

Huyghe C. 1991. Winter growth of autumn-sown white lupin (Lupinus albus L.): main apex growth model. Ann. Bot-London, 67:429-434.

Jannasch R.W., Martin R.C. 1999. The potential for capturing the forage yield of white lupin by intercropping with cereals. Biol. Agric. Hortic., 17:113-130.

Jedel P.E., Helm J.H. 1993. Forage potential of pulse-cereal mixtures in central Alberta. Can. J. Plant Sci., 73:437-444.

Jensen C.R., Joernsgaard B., Andersen M.N., Christiansen J.L., Mogensen V.O., Friis P., Petersen C.T. 2004. The effect of lupins as compared with peas and oats on the yield of the subsequent winter barley crop. Eur. J. Agron., 20:405-418.

Jensen E.S. 1996. Barley uptake of $\mathrm{N}$ deposited in the rhizosphere of associated field pea. Soil Biol. Biochem., 28:159-168.

Juskiw P.E., Helm J.H.. Salmon D.F. 2000. Forage yield and quality for monocrops and mixtures of small grain cereals. Crop Sci., 40:138-147.

Kurdali F., Sharabi N.E., Arslan A. 1996. Rainfed vetchbarley mixed cropping in the Syrian semi-arid conditions. I. Nitrogen nutrition using $15 \mathrm{~N}$ isotopic dilution. Plant Soil, 183:137-148.

Liebman M. 1988. Ecological suppression of weeds in intercropping systems: a review. In: Altieri M.A., Liebman M. (eds.): Weed Management in Agroecosystems: Ecological Approaches. CRC Press, Boca Raton, Florida, USA, 197-212.

Lopez-Bellido L., Fuentes M. 1990. Growth, yield, and yield component of lupin cultivars. Agron. J., 82:1050-1056.

Mariotti M., Ercoli L., Masoni A. 1998. Nitrogen and phosphorus uptake in oat/vetch intercropping. Agric. Ric., 177:37-46.

Mead R., Willey R.W. 1980. The concept of a 'land equivalent ratio' and advantages on yields from intercropping. Exp. Agr., 16:217-228. 
MiPAF 2006. [web page] January 2006, available from internet at the address: http://www.politichea gricole.it/PRODUZIONE/AGRIBIO/HOME.ASP.

Moonen C., Masoni A., Ercoli L., Mariotti M., Bonari E. 2001. Long-term changes in rainfall and temperature in Pisa, Italy. Agr. Med., 131:66-76.

Moreira N. 1989. The effect of seed rate and nitrogen fertilizer on the yield and nutritive value of oat-vetch mixtures. J. Agr. Sci., 112:57-66.

Ofori F., Stern W.R. 1987. Cereal-legume intercropping systems. Adv. Agron., 41:41-90.

Ozturk L., Eker S., Torum B., Cakmak I. 2005. Variation in phosphorus efficiency among 73 bread and durum wheat genotypes grown in a phosphorus-deficient calcareous soil. Plant Soil, 269:69-80.

Palmason F., Danso S.K.A., Hardarson G. 1992. Nitrogen accumulation in sole and mixed stands of sweet blue lupin (Lupinus angustifolius L.), ryegrass and oats. Plant Soil, 142:135-142.

Payne W.A., Chen C., Ball D.A. 2004. Agronomic potential of narrow-leafed and white lupins in the inland Pacific Northwest. Agron. J., 96:1501-1508.

Papastylianou I., Danso S.K.A. 1991. Nitrogen fixation and transfer in vetch and vetch oats mixtures. Soil Biol. Biochem., 23:447-452.

Perry M.W., Dracup M., Nelson P., Jarvis R., Rowland I., French R.J. 1998. Agronomy and farming systems. In: Gladstones J.S., Atkins C., Hamblin J. (eds.): Lupins as Crop Plants. Biology, Production and Utilization, 291-338. CAB International, Wallingford, UK.

Roberts C.A., Moore K.J., Johnson K.D. 1989. Forage quality and yield of wheat-vetch at different stages of maturity and vetch seeding rates. Agron. J., 81:57-60.

Ross S.M., King J.R., O’Donovan J.T., Spaner D. 2004.
Forage potential of intercropping berseem clover with barley, oat, or triticale. Agron. J., 96:1013-1020.

Salawu M.B., Adesogan A.T., Weston C.N., Williams S.P. 2001. Dry matter yield and nutritive value of pea/wheat bi-crops differing in maturity at harvest, pea to wheat ratio and pea variety. Anim. Feed Sci. Tech., 94:77-87.

Snaydon R.W. 1991. Replacement of additive design for competitive studies? J. Appl. Ecol., 28:930-946.

Snedecor G.W., Cochran W.G. 1980. Statistical methods. seventh ed. Iowa State University Press, Ames.

Suong T.T. Cu, Hutson J., Schuller K.A. 2005. Mixed culture of wheat (Triticum aestivum L.) with white lupin (Lupinus albus L.) improves the growth and phosphorus nutrition of the wheat. Plant Soil, 272:143-151.

Thuenissen J. 1997 Application of intercropping in organic agriculture. Biol. Agric. Hortic., 15:251-260.

Trenbath B.R. 1976. Plant interactions in mixed crop communities. In: Papendick P.A., Sanchez P.A., Triplett G.B. (eds.): Multiple Cropping, 129-169. ASA Special Publication 27. ASA, SSSA, CSSA, Madison, WI.

Villegas D., Aparicio N., Blanco R., Royo C. 2001. Biomass accumulation and main stem elongation of durum wheat grown under mediterranean conditions. Ann. Bot-London, 88:617-627.

Willey R.W. 1985. Evaluation and presentation of intercropping advantages. Exp. Agr., 21:119-133.

Withers N.J. 1979. Effects of water stress on Lupinus albus. New Zeal. J. Agric. Res., 22:445-474.

Zadoks J.C., Chang T.I., Konzak C.F. 1974. A decimal code for the growth stages of cereals. Weed Res., 14:415-421.

Zentner R.P., Campbell C.A., Selles F. 1992. Build-up in soil available $\mathrm{P}$ and yield response of spring wheat to seed-placed $\mathrm{P}$ in a 24-year study in the Brown soil zone. Can. J. Soil Sci., 73:173-181. 